ПАРХОМЕНКО М.М., БУЛГАКОВА О.Д.

ПРОБЛЕМИ РЕАЛІЗАЦІЇ ФУНКЦІЇ ПРЕДСТАВНИЦТВА ІНТЕРЕСІВ ГРОМАДЯН
АБО ДЕРЖАВИ ЗА НОВИМИ ЗАСАДАМИ ФУНКЦОНУВАННЯ ІНСИТУТУ
ПРЕДСТАВНИЦТВА ОСОБИ В СУДІ ЗГІДНО 3 ОСНОВНИМ ЗАКОНОМ УКРӒ̈НИ

\title{
PROBLEMS OF REALIZATION OF THE FUNCTION OF REPRESENTATION OF INTERESTS OF CITIZENS OR THE STATE ON NEW PRINCIPLES OF FUNCTIONING OF INSTITUTE OF REPRESENTATION OF THE PERSON IN COURT ACCORDING TO THE BASIC LAW OF UKRAINE
}

\begin{abstract}
У статті досліджуються питання правового регулювання інституту представництва в умовах реформування національного законодавства. Здійснено аналіз норми нової редакції Цивільного процесуального кодексу України щодо процесуального представництва. Стисло проаналізовано види представництва. Виходячи зі змісту поняття «представництво», виділено його характерні ознаки. Визначено основні принципи інституту представництва. Сформульовано основні завдання представництва прокурором інтересів громадянина або держави в суді.

У результаті аналізу понять «представництво в суді», «процесуальне представництво» або «судове представництво» обгрунтовано необхідність використання терміна «процесуальне представництво», характерного для всіх видів судочинства, оскільки він відображає сутність даного поняття, а саме безпосередній захист інтересів клієнта під час розгляду справи в суді. Ця особливість відрізняє дане представництво від цивільного представництва або так званого «непроцесуального представництва» (представництва інтересів у різних державних органах).

На підставі проведеного аналізу судової практики визначено правовий статус прокурора у цивільному та господарському процесі. Практика Верховного Суду показує, що одна лише довіреність не може підтвердити повноваження працівника (юрисконсульта) представляти інтереси юридичної особи або державного органу шляхом самопредставництва. Для підтвердження повноважень на участь у справі шляхом самопредставництва працівник (юрисконсульт) зобов'язаний надати: докази того, що особа займає певну посаду (наказ, трудовий договір), а також докази, що дають змогу визначити обсяг повноважень зазначеної посадової особи (Статут, положення, трудовий договір (контракт)). Досліджено окремі проблемні аспекти правового забезпечення представництва прокурором інтересів громадянина або держави в суді. Проаналізовано співвідношення інституту представництва із загальними завданнями прокурорської діяльності.

Виявлено прогалини та недоліки в законодавчому регулюванні представництва прокурором інтересів громадянина або держави в суді, надано рекомендації та роз'яснення щодо їх усунення.
\end{abstract}

Ключові слова: процесуальне представництво, прокурор, представництво, інтереси держави, суспільний інтерес.

The article examines the issues of legal regulation of the institution of representation in the context of reforming national legislation. The analysis of the norm of the new edition of the Civil Procedural Code of Ukraine on procedural representation is carried out. The types of representation are briefly analyzed. Based on the content of the concept

(C) ПАРХОМЕНКО М.М. - кандидат юридичних наук, доцент, доцент кафедри історії та права (Донецький національний технічний університет)

(C) БУЛГАКОВА О.Д. - здобувачка кафедри кримінального права (Національна академія внутрішніх справ) 
of «representation» highlighted its characteristics. The basic principles of the institute of representation are determined. The main tasks of the prosecutor's representation of the interests of a citizen or the state in court are formulated.

As a result of the analysis of the concepts «representation in court», «procedural representation» or «judicial representation» the necessity to use the term «procedural representation» characteristic of all types of legal proceedings is substantiated as it reflects essence of this concept, namely direct protection of interests of the client. in court. This feature distinguishes this representation from civil representation or so-called «non-procedural representation» (representation of interests in various state bodies).

Based on the analysis of judicial practice, the legal status of the prosecutor in civil and commercial proceedings is determined. The case law of the Supreme Court shows that a power of attorney alone cannot confirm the authority of an employee (legal adviser) to represent the interests of a legal entity or a state body through self-representation. To confirm the authority to participate in the case through self-representation, the employee (legal adviser) must provide: evidence that the person holds a certain position (order, employment contract), as well as evidence to determine the scope of authority of the official (Statute, regulations, employment agreement (contract)). Some problematic aspects of the legal support of the prosecutor's representation of the interests of a citizen or the state in court have been studied. The correlation of the institute of representation with the general tasks of prosecutorial activity is analyzed.

Gaps and shortcomings in the legislative regulation of the prosecutor's representation of the interests of a citizen or the state in court have been identified, recommendations and explanations have been provided for their elimination.

Key words: procedural representation, prosecutor, representation, state interests, public interest.

Вступ. Актуальність теми дослідження зумовлена реформою місця прокуратури та адвокатури в системі правосуддя та новими принципами функціонування інституту представництва особи в суді. 30 вересня 2016 року набрав чинності Закон України від 2 червня 2016 року № 1401-VIII «Про внесення змін до Конституції України (щодо правосуддя)» [1]. Ці зміни до Основного Закону України встановили особливе місце прокуратури та адвокатури в системі правосуддя та нові засади функціонування інституту представництва особи в суді. Так, згідно зі статтею 131-1 Конституції України, у країні діє прокуратура, яка підтримує державне обвинувачення в суді; організовує і забезпечує процесуальне керівництво досудовим розслідуванням, вирішує інші питання в ході кримінального судочинства відповідно до закону, здійснює нагляд за негласними та іншими слідчими і розшуковими діями правоохоронних органів; представлення інтересів держави в суді у виняткових випадках і в порядку, встановленому законом. Разом із тим, відповідно до статті 131-2 Конституції України, для надання професійної юридичної допомоги в Україні існує адвокатура, і тільки адвокат представляє в суді іншу особу, а також захищає від кримінального переслідування; законом можуть бути встановлені винятки для представництва в суді по трудових спорах, спорах про захист соціальних прав, про вибори і референдуми, у справах неповнолітніх, а також для представництва неповнолітніх або осіб, визнаних судом недієздатними або обмежено дієздатними [2].

Оскільки функція прокуратури щодо представництва займає особливе місце в діяльності прокуратори, то реформа цієї функції потребує дослідження з боку науковців. Питанням вивчення інституту представництва особи в суді займалася низка українських учених, таких як: Г.А. Васильєва, Т.В. Степанова, О.В. Драган, Т.О. Дунас, К.А. Гузе, В.Г. Андрусяк, М.В. Капустіна, М. Стефанчук, В.С. Бабкова, М.В. Селіванова та ін. Але в контексті прийняття нового Закону України «Про внесення змін до Конституції України (щодо правосуддя)» вони донині не отримали відповідної теоретичної бази.

Постановка завдання. Метою статті є формулювання теоретичних та практичних рекомендацій щодо правильного практичного застосування нового законодавства щодо представництва інтересів громадянина або держави в суді. Певні прогалини у вивченні проблеми прокурорського представництва вимагають внесення необхідних змін, обгрунтованих необхідністю істотного підвищення якості представництва особи в суді. Для цього необхідно встановити сутність і поняття представницької діяльності. 
Результати дослідження. Учені розрізняють поняття «представництво в суді», «процесуальне представництво» або «судове представництво». Одразу слід зазначити, що Цивільний процесуальний кодекс України, Цивільний процесуальний кодекс України та КАС України 2017 року містять лише термін «представництво». У вітчизняній юридичній літературі використовуються різні терміни: «представництво в суді», «процесуальне представництво» або «судове представництво». Вивчивши наукові праці із цього питання, можна зазначити, що вони використовуються як тотожні поняття [3]. Автори підтримують думку вчених про необхідність використання терміна «процесуальне представництво», характерного для всіх видів судочинства, оскільки він відображає сутність даного поняття, а саме безпосередній захист інтересів клієнта під час розгляду справи в суді. Ця особливість також відрізняє дане представництво від цивільного представництва, або так званого «непроцесуального представництва» (представництва інтересів у різних державних органах). Представництво визначається певними особливостями:

1) цивільні права та обов'язки належать одній особі і здійснюються безпосередньо іншою;

2) представник учиняє певні юридичні дії (вчинення тільки фактичних (неюридичних) дій не входить до компетенції представництва);

3) представник діє не від свого імені, а від імені іншої особи;

4) представник діє виключно в межах наданих йому повноважень [4];

5) правові наслідки настають не для представника, а для особи, яку він представляс. Якщо угода, укладена представником, заподіяла збитки контрагенту, то зобов'язаною стороною буде не представник, а особа, яка дала йому повноваження на вчинення цього правочину [5];

6) представництво можливе тільки щодо суб'єкта права. Тобто особою, яка представлена, може бути тільки особа, яка має хоча б правоздатність. I якщо стосовно фізичних осіб відповідно до сучасної доктрини цивільного права ця умова не має практичного значення, оскільки кожна особа дієздатна з моменту народження, то щодо юридичних осіб ця обставина відіграє вирішальну роль, оскільки правоздатність останніх може виникнути тільки за наявності певних умов, передбачених законом, а до цього така особа не є суб'єктом права і не може набувати права та обов'язки ні особисто, ні через представника [6].

До прийняття Закону України «Про внесення змін до Господарського процесуального кодексу України, Цивільного процесуального кодексу України, Кодексу адміністративного судочинства України та інших законодавчих актів» від 03.10.2017 № 2147-VIII [7], Цивільний процесуальний кодекс України визначав осіб, які можуть бути представниками за допомогою такої статті:

Стаття 40. Особи, які можуть бути представниками

1. Представником у суді може бути адвокат або інша особа, яка досягла вісімнадцятирічного віку, має цивільну процесуальну дієздатність і належно посвідчені повноваження на здійснення представництва в суді за винятком осіб, визначених статтею 41 цього Кодексу.

2. Одна і та ж особа не може одночасно бути представником іншої сторони, третіми особами, що пред'являють самостійні вимоги щодо предмета спору або беруть участь у справі по іншій стороні [8].

Цивільний процесуальний кодекс України зі змінами, внесеними у 2017 році вищезазначеним законом, осіб, які можуть бути представниками:

Стаття 60. Особи, які можуть бути представниками

1. Представником у суді може бути адвокат або законний представник.

2. Під час розгляду спорів, що виникають із трудових правовідносин, а також справ у незначних спорах (малозначних справах) представником може бути особа, яка досягла вісімнадцятирічного віку і володіє цивільною процесуальною дієздатністю, за винятком осіб, визначених статтею 61 цього Кодексу.

3. Органи або інші особи, яким законом надано право звертатися до суду в інтересах неповнолітніх або неповнолітніх, або особи, визнані судом недієздатними або обмежено дієздатними, представляються в суді своїми посадовими особами за винятком випадків, коли такі органи та особи є стороною або третьою особою у справі.

4. Одна і та ж особа може одночасно бути представником декількох позивачів або декількох відповідачів або декількох третіх осіб від однієї і тієї ж сторони за умови відсутності між ними конфлікту інтересів [9].

Зміст статті 60 Цивільного процесуального кодексу України відповідає сучасним змінам Закону України від 2 червня 2016 року № 1401-VIII «Про внесення змін до Конституції України (щодо правосуддя)». Згідно зі змінами, встановлювався поступовий перехід на представництво 
інтересів у судах тільки адвокатами (так звана «монополія адвокатури»): 31 січня 2017 року - у Верховному Суді та касаційних судах; у судах апеляційної інстанції - 31 січня 2018 року; у судах першої інстанції - 31 січня 2019 року. Представництво органів державної влади та органів місцевого самоврядування в судах виключно прокурорами або адвокатами мало здійснюватися 3 1 січня 2020 року.

Процесуальні кодекси, які набрали чинності у грудні 2017 року, закріпили таку схему процесуального представництва юридичних осіб у суді:

- самостійна участь (або самопредставництво);

- участь у судовому процесі через свого керівника або члена виконавчого органу, уповноваженого діяти від імені юридичної особи відповідно до Закону, статуту, положення;

- участь через представника-адвоката, уповноваженого діяти на підставі довіреності або ордера, виданих на підставі договору про правову допомогу.

На прикладі справи № 17/495-08 Господарського суду м. Києва ми з'ясуємо, з чого складається процесуальне представництво, які існують проблеми з належним представництвом юридичної особи в суді і що є доказом належного представництва. Позивач, товариство з обмеженою відповідальністю «Макро», звернувся з позовом до товариства з обмеженою відповідальністю «СТБ-Суми» за участю третьої особи, яка не пред'являє самостійних вимог із предмета спору, на боці відповідача - Сумської міської ради про визнання права власності. Подана апеляційна скарга була підписана представником Ради Заїкою І.Б., у підтвердження повноважень якого до касаційної скарги була додана копія довіреності № 2469/03.02.02-08 від 27.12.2019.

Суд уважає за необхідне звернути увагу позивача на вимоги частини третьої статті 56 ГПК України, згідно з якою юридична особа незалежно від порядку ії створення бере участь у справі через свого керівника, члена виконавчого органу, іншу особу, уповноважену діяти від їі імені відповідно до Закону, статуту, нормативних правових актів, трудового договору (контракту) (самопредставництво юридичної особи) або через представника.

Відповідно до вимог частини першої статті 58 ГПК України, представником у суді може бути адвокат або законний представник.

Так, вищеназвані норми законодавства передбачають можливість процесуального представництва юридичної особи як у порядку самопредставництва, так і іншими особами, які $\epsilon$ представниками юридичної особи.

У порядку самопредставництва юридична особа може бути представлена його керівником або іншими особами, повноваження яких визначено законодавством або установчими документами.

Однак суд звертає увагу на те, що сама довіреність, яка додається до касаційної скарги, не може підтвердити повноваження Заїки I.В. як заступника начальника відділу правового та кадрового забезпечення представництва інтересів Департаменту Сумської міської ради та міського голови відділу забезпечення ресурсних виплат Сумської міської ради представляти інтереси ради в судах України в порядку самопредставництва, оскільки скарга не супроводжується доказами того, що Заїка I.В. займає зазначену посаду, а також докази, що дають змогу встановити обсяг повноважень зазначеної посадової особи (Статут, положення, трудовий договір (контракт)).

Ці докази також відсутні в матеріалах справи, що не дає змоги суду самостійно перевірити обсяг повноважень представника Ради.

Таким чином, Рада повинна надати документи, що засвідчують повноваження Заїки I.В. представляти інтереси ради в порядку самостійного представництва в судах України, відповідно до вимог статті 56 ГПК України. [10].

У сучасній судовій практиці існує проблема наявності у прокуратури правових підстав представляти інтереси територіальної громади в особі відповідних місцевих рад у судах. Особливо вчені стали звертати увагу на законність здійснення прокуратурою таких повноважень у зв'язку з набранням чинності нового Закону «Про прокуратуру» від 14 жовтня 2014 року № 1697-VII [11].

Відповідно до частини 2 статті 45 Цивільного процесуального кодексу України (далі ЦПК України), з метою представництва інтересів громадянина або держави в суді прокурор у межах установлених законом повноважень звертається в суд із позовною заявою (заявою), бере участь у розгляді справ за його позовами, а також може за власною ініціативою вступити у справу, у якій відкрито провадження за позовом інших осіб, на будь-якій стадії іiі розгляду, подати апеляційну, касаційну скаргу, заяву про перегляд судового рішення Верховним Судом України, про перегляд судового рішення за нововиявленими обставинами [9]. 
Аналогічні положення містяться у частині 3 статті 2 Господарського процесуального кодексу України (ГПК): «Прокурор, який звертається до Господарського суду в інтересах держави, у позовній заяві самостійно визначає, у чому полягає порушення інтересів держави, та обгрунтовує необхідність їх захисту, а також зазначає орган, уповноважений державою здійснювати відповідні функції у спірних відносинах. Якщо такого органу немає або він не уповноважений звертатися до арбітражного суду, прокурор указує про це в позовній заяві» [12]. Прокурор, звертаючись до Господарського суду в інтересах держави, повинен обгрунтувати наявність підстав для представлення інтересів держави в суді, передбачених частиною третьою статті 23 Закону України «Про прокуратуру». Прокурор представляє у суді законні інтереси держави у разі порушення або загрози порушення інтересів держави, якщо захист цих інтересів не здійснюється або неналежним чином здійснюється державним органом, органом місцевого самоврядування або іншим суб'єктом влади, до компетенції якого віднесено відповідні повноваження, а також за відсутності такого органу.

Отже, у новому Законі «Про прокуратуру» є норми, що дають певні підстави прокурору представляти інтереси органів місцевого самоврядування в суді, якими також є місцеві ради.

У Постанові Конституційного Суду України у справі про конституційні подання Вищого Арбітражного суду України та Генеральної прокуратури України щодо офіційного тлумачення положень статті 2 Арбітражного процесуального кодексу України (справа про представлення прокуратурою України інтересів держави в арбітражному суді) від 08.04.99 № 3-РП/99 Конституційний Суд України роз'яснив поняття «інтереси держави». Висловлюються міркування про те, що інтереси держави відрізняються від інтересів інших учасників суспільних відносин. В основі перших завжди лежить необхідність здійснення загальнодержавних (політичних, економічних, соціальних та ін.) заходів, програм, спрямованих на захист суверенітету, територіальної цілісності, державного кордону України, забезпечення її державної, економічної, інформаційної, екологічної безпеки, захист земель як національного багатства, захист прав усіх суб'єктів власності та економічних прав тощо (пункт 3 мотиваційної частини).

Інтереси держави можуть збігатися повністю, частково або не збігатися зовсім з інтересами державних органів, державних підприємств і організацій, або з інтересами господарюючих суб'єктів, що мають частку державної власності у статутному капіталі. Однак держава може бачити свої інтереси не тільки в їхній діяльності, а й у діяльності приватних підприємств і товариств.

Беручи до уваги той факт, що «інтереси держави» є оціночним поняттям, прокурор або його заступник у кожному конкретному випадку самостійно визначає (із посиланням на законодавство, на підставі якого подається позов), яке саме порушення матеріальних чи інших інтересів держави мало або може мати місце, обгрунтовує в позовній заяві необхідність їх захисту й указує орган, уповноважений державою здійснювати відповідні функції у спірних відносинах (пункт 4 мотивувальної частини) [13].

У Постанові Касаційного господарського суду від 26.06.2018 у справі № 910/20517/16 за позовом керівника місцевої прокуратури в інтересах держави до облдержадміністрації Товариство за участю третіх осіб не пред'являє самостійних вимог щодо предмета спору на стороні позивача - обласна дорожня служба, Державне агентство автомобільних доріг України (Укравтодор) про визнання недійсними наказу та договору оренди земельної ділянки, КГС ВС погодилися 3 висновками судів попередніх інстанцій про відсутність підстав для задоволення позову прокурора.

Суд касаційної інстанції зазначив, що під час подачі позову по даній справі в інтересах держави без указівки органу, уповноваженого здійснювати функції держави у спірних правовідносинах, прокурор стверджував, що центральним органом виконавчої влади, що забезпечує реалізацію державної політики у сфері нагляду (контролю) в агропромисловому комплексі, $є$ Державна інспекція сільського господарства України, яка була ліквідована відповідно до пункту 7 пункту 2 Постанови Кабінету Міністрів України від 10.09.2014 п. 442 «Про оптимізацію системи органів виконавчої влади» [14].

Однак у позовній заяві прокурора прямо не зазначено, що у спірних правовідносинах відсутній орган, уповноважений здійснювати функції держави, або що такий орган не має повноважень на звернення до Господарського суду, як того вимагають положення норм, що регулюють порядок подання прокурором інтересів держави у господарському процесі.

Суд касаційної інстанції зазначив, що в даному разі прокурор фактично подав позов про захист прав та інтересів регіональної дорожньої служби, яка є користувачем земельної ділянки, щодо якої виник даний спір, і наділена правом самостійно захищати свої права та інтереси, у тому числі в судовому порядку. 
Висновки. Виходячи 3 результатів узагальнення судової практики, можна зробити висновок, що з прийняттям нового Закону України «Про прокуратуру» та нової редакції Господарського процесуального кодексу України статус прокурора в господарському процесі дещо змінився. Сьогодні Конституція України, спеціальний закон та відповідне процесуальне законодавство чітко встановлюють, що прокурор може представляти інтереси держави лише у випадках, передбачених законом. Водночас, згідно з уже сформованою судовою практикою, головною особливістю представлення прокурором інтересів держави $\epsilon$ винятковість таких справ. Аналіз практики Верховного Суду також показує, що одна лише довіреність не може підтвердити повноваження працівника (юрисконсульта) представляти інтереси юридичної особи або державного органу шляхом самопредставництва. Для підтвердження повноважень на участь у справі шляхом самопредставництва працівник (юрисконсульт) зобов'язаний надати:

докази того, що особа займає певну посаду (наказ, трудовий договір), а також докази, що дають змогу визначити обсяг повноважень зазначеної посадової особи (Статут, положення, трудовий договір (контракт)). При цьому відповідний трудовий договір (контракт) повинен містити положення про повноваження юрисконсульта представляти інтереси юридичної особи в суді. Відсутність відповідних положень у трудовому договорі (положенні/посадовій інструкції) є підставою для відмови в допуску до справи.

\section{Список використаних джерел:}

1. Про внесення змін до Конституції України (щодо правосуддя) : Закон України від 2 червня 2016 року № 1401-VIII. Відомості Верховної Ради. 2016. № 28. Ст. 532.

2. Конституція України : Закон України від 28.06.1996 № 254к/96-ВР. Відомості Верховної Ради Украӥни. 1996. № 30. Ст. 141.

3. Ханик-Посполітак Р.Ю. Представництво в цивільному процесі за новим Цивільним процесуальним кодексом України. Наукові записки НаУКМА. Юридичні науки. 2018. Т. 1. C. $50-54$.

4. Галабурда Н.А. Особливості змісту поняття представництва у цивільному праві України. Актуальні проблеми вітчизняної юриспруденції. 2012. Вип. 3. С. 21-26.

5. Бірюков І.А., Заіка Ю.О., Співак В.М. Цивільне право України. Загальна частина. Київ : Наук. думка, 2000. 304 с.

6. Крупко П. Суб'єкти добровільного представництва за цивільним правом. Право України. 2002. № 5. С. 105-109.

7. Про внесення змін до Господарського процесуального кодексу України, Цивільного процесуального кодексу України, Кодексу адміністративного судочинства України та інших законодавчих актів : Закон України від 03.10.2017 № 2147-VIII. Відомості Верховної Ради. 2017. № 48. Ст. 436.

8. Цивільний процесуальний кодекс України : Закон України, редакція від 03.08.2017. Відомості Верховної Ради Украӥни. 2004. № 40-42. Ст. 492.

9. Цивільний процесуальний кодекс України : Закон України, редакція від 13.08.2020. Відомості Верховної Ради України. 2004. № 40-42. Ст. 492.

10. Ухвала Касаційного господарського суду Верховного Суду по справі № 17/495-08. URL:http:// www.reyestr.court.gov.ua/Review/47624705.

11.Про прокуратуру : Закон України від 14 жовтня 2014 року № 1697-VII. Відомості Верховної Ради. 2015. № 2-3. Ст. 12.

12. Господарський процесуальний кодекс України : Закон України від 6 листопада 1991 року № 1798-XII. Відомості Верховної Ради України. 1992. № 6. Ст. 56.

13. Рішення Конституційного Суду України у справі за конституційними поданнями Вищого арбітражного суду України та Генеральної прокуратури України щодо офіційного тлумачення положень статті 2 Арбітражного процесуального кодексу України (справа про представництво прокуратурою України інтересів держави в арбітражному суді) від 8 квітня 1999 року. Справа № 1-1/99, № 3-pп/99. URL: http://zakon.rada.gov.ua/laws/show/v003p710-99\#Text.

14. Постанова касаційного Господарського суду від 26.06.2018 по справі № 910/20517/16. URL: http:// www.reyestr.court.gov.ua/Review/47624705. 